Article

\title{
Thermal Behavior of a Building with Incorporated Phase Change Materials in the South and the North Wall
}

\author{
Maria T. Plytaria, Christos Tzivanidis, Evangelos Bellos*(D), Ioannis Alexopoulos \\ and Kimon A. Antonopoulos
}

Thermal Department, School of Mechanical Engineering, National Technical University of Athens, Heroon Polytechniou 9, 15773 Zografou, Greece; maplyt@central.ntua.gr (M.T.P.); ctzivan@central.ntua.gr (C.T.); alexxop@hotmail.com (I.A.); kanton@central.ntua.gr (K.A.A.)

* Correspondence: bellose@central.ntua.gr

Received: 16 October 2018; Accepted: 18 December 2018; Published: 21 December 2018

\begin{abstract}
Energy consumption in the building sector is responsible for a very large amount of electricity consumption worldwide. The reduction of this consumption is a crucial issue in order to achieve sustainability. The objective of this work is to investigate the use of phase change materials (PCMs) in the building walls in order to reduce the heating and the cooling loads. The novelty of this work is based on the investigation of different scenarios about the position of the PCM layer in the south and the north walls. PCMs can improve the thermal performance and the thermal comfort of a building due to their ability to store large amounts of thermal energy in latent form and so to reduce the temperature fluctuations of the structural components, keeping them within the desired temperature levels. More specifically, this work presents and compares the heating loads, the cooling loads and the temperature distribution of a building in Athens (Greece), with and without PCMs in different positions in the south wall and in the north walls. The simulation is performed with the commercial software TRNSYS 17, using the TRNSYS component: type 1270 (PCM Wall). The results proved that the maximum energy savings per year were achieved by the combination of the insulation and the PCM layer in the north and south walls. More specifically, the reductions in the heating and the cooling loads were found to be $1.54 \%$ and $5.90 \%$, respectively. Furthermore, the temperature distribution with the use of a PCM layer is the most acceptable, especially during the summer period.
\end{abstract}

Keywords: phase change materials; building thermal behavior; TRNSYS; heating-cooling loads

\section{Introduction}

The building sector is one of the most energy consuming sectors, and it is responsible for about the $30 \%-40 \%$ of the world's total energy consumption. The utilization of alternative and renewable energy sources in the building sector is a critical issue which has to be delivered in order to achieve sustainability [1]. Solar energy exploitation is an important weapon for reducing electricity and fossil fuel utilization in the building sector [2]. Solar energy is an abundant energy source which can be converted either to useful heat or electricity. Greece is a country with high solar potential, which is in the range of $1400 \mathrm{kWh} / \mathrm{m}^{2}$ to $1800 \mathrm{kWh} / \mathrm{m}^{2}$ per year. In Athens, the solar potential is about $1600 \mathrm{kWh} / \mathrm{m}^{2}$ [3], and it is a promising value for the cover of the energy loads with the solar energy utilization.

The proper solar energy exploitation of the solar irradiation from the building envelope can be achieved with the use of phase change materials (PCM) in the external walls [4]. The PCM aids the proper energy management of the incident solar energy in order to reduce the energy loads of 
the building cell. The use of PCMs was first introduced in the 1980s [5], and there has been a lot of evolution since then [6]. The proper location of the PCM in the structural components is a critical issue, and it determines the performance enhancement margins. In the literature, different locations for the PCM layer have been examined, for example, close to the exterior wall surface [7], close to the interior wall surface [8] and close to the intermediate insulation layer [9].

Over the last few years, the simulation of the PCMs in buildings has been conducted using the proper software. TRNSYS and EnergyPlus are well-known examples of software that have been used in numerous studies [10]. TRNSYS (TRaNsient System Simulation) software is applied in many studies with PCMs, especially in the cases that the building has to be coupled with another installation (e.g., solar heating system). Ibanez et al. [11] created a simple model with TRNSYS in order to simulate the thermal behavior of a building with PCMs. They used the active layers in order to control the PCM utilization properly. Generally, the application of PCM in TRNSYS needs the use of external type coupled with the Building component (type 56). For example, some types for the PCM are the following: type 101 [12], type 241 [13], type 260 [14], type 285 [15], type 399 [16], type 3258 [17].

In the literature, there are studies about building with PCMs which have been simulated in TRNSYS. Stritih et al. [18] examined the use of PCMs in the structural components of a building in order to make it a nearly zero energy building. They stated that the weather data plays a significant role in the building thermal behavior. Fateh et al. [19] examined the use of PCM in a light-weight building, and they found the optimum melting temperature of the PCMs to be $23^{\circ} \mathrm{C}$. Lu et al. [20] found that the use of PCMs in the underfloor heating system leads to a $6 \%$ decrease in the heating loads of the building. Derradji et al. [21] found that the use of PCMs in a wall was able to increase the indoor temperature by up to $4{ }^{\circ} \mathrm{C}$ in the winter and to decrease the indoor temperature by up to $7^{\circ} \mathrm{C}$ in the summer.

In this work, an alternative PCM component, the type 1270 is examined for a building application. This type has been developed by the Thermal Energy System Specialists (TESS) Company for TRNSYS [22]. This component is designed to interact directly with type56 (multi-zone building) [23], and so it is able to perform easy calculations. The proper operation of this component is done by specifying the physical properties of the PCM (density, specific heat, melting temperature, freezing temperature and latent heat of fusion). Also, there is the alternative choice of using the commercially available "BioPCM" manufactured by Phase Change Energy Solutions [24]. The novelty of this work is the parametric investigation of the "BioPCM" in different locations in the south and in the north wall of a building in Athens (Greece). Also, different insulation scenarios are examined and, in any case, the heating and the cooling loads are calculated. Athens is a location with high cooling loads in the summer and significant heating loads in the winter, and so it is an ideal selection for testing the PCM operation during the period of a year.

\section{Materials and Methods}

\subsection{The Examined Building}

In this work, the incorporation of PCM in walls of a building in Athens is theoretically evaluated using TRNSYS software. The examined building is an office, which has a floor area of $100 \mathrm{~m}^{2}$ and consists of four external walls, while there are no internal walls. The parameters of the investigated building have typical values which are usually applied in building thermal behavior simulations. The floor shape of the building is a square, and it is orientated into the four directions. Double windows are placed in the south, in the east and in the west directions. The building operation program starts at 8:00 a.m. and ends at 6:00 p.m. for all the examined period. During these hours, it is assumed that 5 people work inside the building, the equipment load is equal to $250 \mathrm{~W}$, and the lighting load is about $500 \mathrm{~W}$. Table 1 gives all the parameters of the examined building [25].

The wall reference structure is the following: $1.5 \mathrm{~cm}$ plaster, $12 \mathrm{~cm}$ brick, $6 \mathrm{~cm}$ insulation, $12 \mathrm{~cm}$ brick and $1.5 \mathrm{~cm}$ plaster. The roof consists of $24 \mathrm{~cm}$ concrete, $7 \mathrm{~cm}$ insulation and $1.5 \mathrm{~cm}$ plaster. 
Table 2 gives, analytically, the physical thermal properties of used materials, which are utilized in this work. It is useful to state that the desired temperatures were set to be $20{ }^{\circ} \mathrm{C}$ in winter and to $26^{\circ} \mathrm{C}$ in summer [26,27]. The use of PCMs is performed using the proper type in TRNSYS 17, type 1270. This type belongs to the Thermal Energy System Specialists (TESS) library.

Different cases are examined in this work:

Case 1: The PCM layer is located in the south wall, after the insulation layer.

Case 2: The PCM layer is located in the south wall, before the insulation layer.

Case 3: The PCM layer is located in the south wall, before the insulation layer and in the north wall, before the insulation layer.

Case 4: The PCM layer is located in the south wall, before the insulation layer and in the north wall, after the insulation layer.

Table 3 includes the physical properties of PCM, which is used in simulations. In addition, Figure 1 depicts the examined cases.

Table 1. Building parameters [25].

\begin{tabular}{cc}
\hline Parameter & Value \\
\hline Floor area & $100 \mathrm{~m}^{2}$ \\
Height & $3 \mathrm{~m}$ \\
South double window & $6 \mathrm{~m}^{2}$ \\
East double window & $3 \mathrm{~m}^{2}$ \\
West double window & $3 \mathrm{~m}^{2}$ \\
Wall U-value & $0.51 \mathrm{~W} / \mathrm{m}^{2} \mathrm{~K}$ \\
Specific Gains (equipment) & $250 \mathrm{~W}$ \\
Persons & 5 \\
Specific lighting & $5 \mathrm{~W} / \mathrm{m}^{2}$ \\
Shading factor & $60 \%$ \\
Window U-value & $1.4 \mathrm{~W} / \mathrm{m}^{2} \mathrm{~K}$ \\
Roof U-Value & $0.47 \mathrm{~W} / \mathrm{m}^{2} \mathrm{~K}$ \\
\hline
\end{tabular}

Table 2. Physical properties of building materials [23,25].

\begin{tabular}{cccc}
\hline Materials & $\begin{array}{c}\text { Density } \\
\boldsymbol{\rho}\left(\mathbf{k g} / \mathbf{m}^{\mathbf{3}}\right)\end{array}$ & $\begin{array}{c}\text { Thermal Conductivity } \\
\boldsymbol{k}(\mathbf{W} / \mathbf{m K})\end{array}$ & $\begin{array}{c}\text { Specific Heat Capacity } \\
\boldsymbol{C}_{\boldsymbol{p}}(\mathrm{J} / \mathbf{k g K})\end{array}$ \\
\hline Plaster & 2000 & 1.39 & 1000 \\
Brick & 1800 & 0.89 & 1000 \\
Insulation & 25 & 0.04 & 1500 \\
Concrete & 1400 & 1.13 & 1000 \\
\hline
\end{tabular}

Table 3. Physical properties of PCM, which is used in simulations [24].

\begin{tabular}{cc}
\hline Product BioPCM & Q25/M91 \\
\hline Weight per area & $6.44 \mathrm{~kg} / \mathrm{m}^{2}$ \\
Thickness & $20 \mathrm{~mm}$ \\
Dimensions /Width & $450 \mathrm{~mm}$ \\
Melting temperature & $25^{\circ} \mathrm{C}^{\mathrm{a}}$ \\
Freezing temperature point & $21^{\circ} \mathrm{C}$ a \\
Density (liquid) & $850 \mathrm{~kg} / \mathrm{m}^{3}$ \\
Density (solid) & $1400 \mathrm{~kg} / \mathrm{m}^{3}$ \\
Specific heat capacity (liquid) & $2200 \mathrm{~J} / \mathrm{kgK}$ \\
Specific heat capacity (solid) & $4500 \mathrm{~J} / \mathrm{kgK}$ \\
Thermal conductivity (liquid) & $0.15 \mathrm{~W} / \mathrm{mK}$ \\
Thermal conductivity (solid) & $2.5 \mathrm{~W} / \mathrm{mK}$ \\
Latent heat storage capacity & $175 \mathrm{~kJ} / \mathrm{kg}$ \\
\hline
\end{tabular}

a The temperatures marked are close proximities of the 'true' melting/freezing temperatures because PCMs melt within a small range of temperatures; ${ }^{b}$ depending on the formulation and application of the product. 


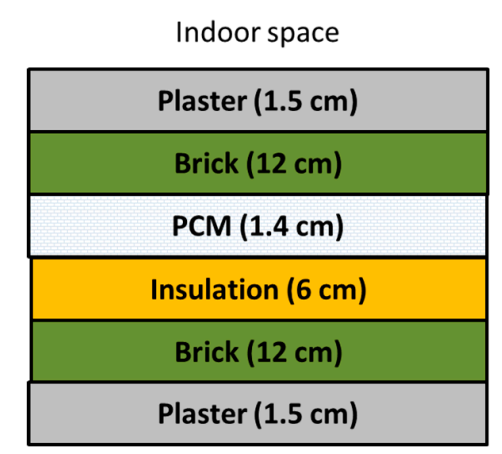

Ambient

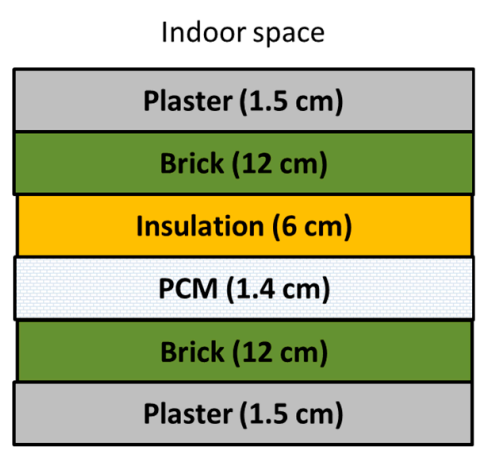

Ambient

(a) PCM after the insulation

(b) PCM before the insulation

Figure 1. (a) PCM after the insulation case; (b) PCM before the insulation case.

\subsection{Type 1270 for $P C M$}

According to TESSLibs3-Mathematical Reference, the type 1270 is a simple mathematic model because the freeze/thaw process is assumed to be done at a constant temperature level. The PCM has a constant specific heat capacity in the solid state and another in the liquid state.

When the PCM material is fully frozen, the temperature at the end of a time step is given by:

$$
T_{\text {final }}=T_{\text {initial }}+\frac{q_{1}+q_{2}}{m_{p c m} \cdot c_{p, \text { solid }}} .
$$

When the PCM material is fully thawed, the temperature at the end of a time step is given by:

$$
T_{\text {final }}=T_{\text {initial }}+\frac{q_{1}+q_{2}}{m_{p c m} \cdot c_{p, l i q u i d}}
$$

where $q_{1}$ and $q_{2}$ are the quantities of energy input in the PCM from the boundary wall layers, $m_{\mathrm{PCM}}$ is the mass of the PCM, $C_{p \text {,solid }}$ is the specific heat capacity at the solid state of PCM and $C_{p, \text { liquid }}$ is the specific heat capacity at the liquid state of PCM.

When the PCM material is in the transition phase, the final and the initial temperature levels are equal. In these cases, the type 1270 keeps in its memory the stored energy amount in order to know when there would be a phase change. This technique is able to adjust properly the values of the specific heat capacities, and the temperature levels which are the boundary conditions in the wall components.

To conclude, the type 1270 is combined with building type (type 56), and the PCM temperatures are set as boundary conditions in the examined walls. The location of the PCM in the wall determines the boundary conditions in the respective positions in the structural material. Moreover, it is useful to state that type 1270 calculates the temperature of the PCM layer $\left(T_{P C M}\right)$. The proper heat fluxes are calculated, and these have an influence on the indoor space temperature. More specifically, the heat flux in the outside surface of each boundary wall is given by the type 56 as an output "QCOMO" which is connected as an input into the PCM type.

Furthermore, it is useful to state that TRNSYS is software which operates with components that the user selects with a "drag and drop" procedure. The proper details are determined by the user when there are different conditions than the default. The building envelope is determined by selecting the proper layers in the edit mode of type 56. Lastly, a sensitivity analysis has been performed in order to select the time step at 10 minutes. Regarding model validation, it has to be said that the type 1270 has been validated with experimental results in References [28,29], this can be adopted as a reliable model. 


\subsection{Weather Data}

The weather data has been taken from the TRNSYS libraries, using the Typical Meteorological Year component. The calculations were conducted for the coldest month (January) and for the warmest month (July) of the year for the climate conditions of Athens (Greece). More specifically, the yearly coldest day and the warmest, according to Figure 2, have also been investigated on a deeper basis. The ambient temperatures for January and July are given in Figure $3 \mathrm{a}, \mathrm{b}$ respectively.

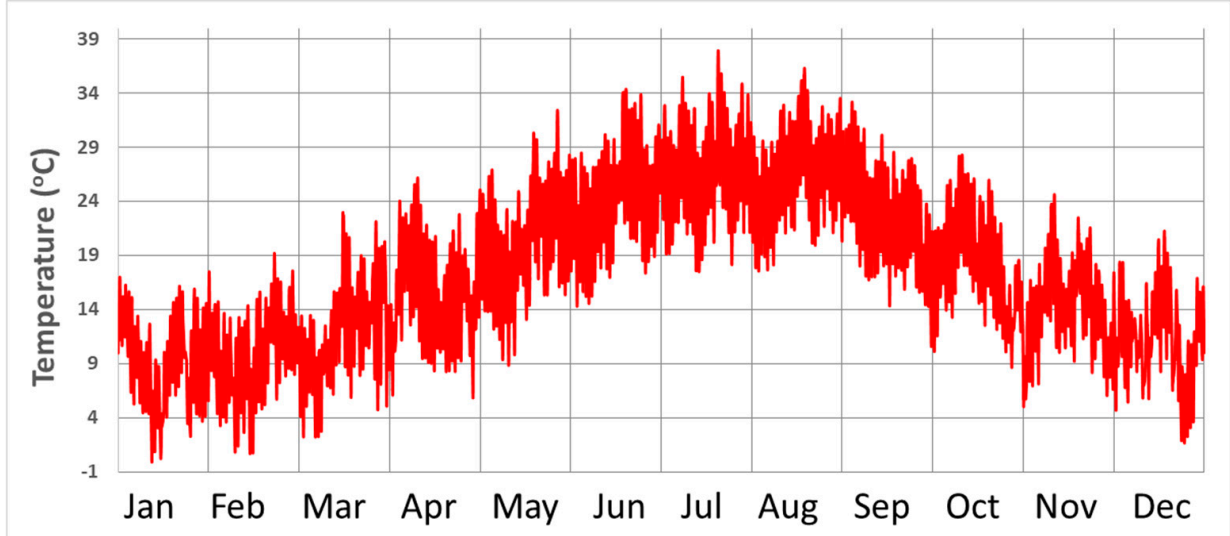

Figure 2. Ambient temperature of the whole year.

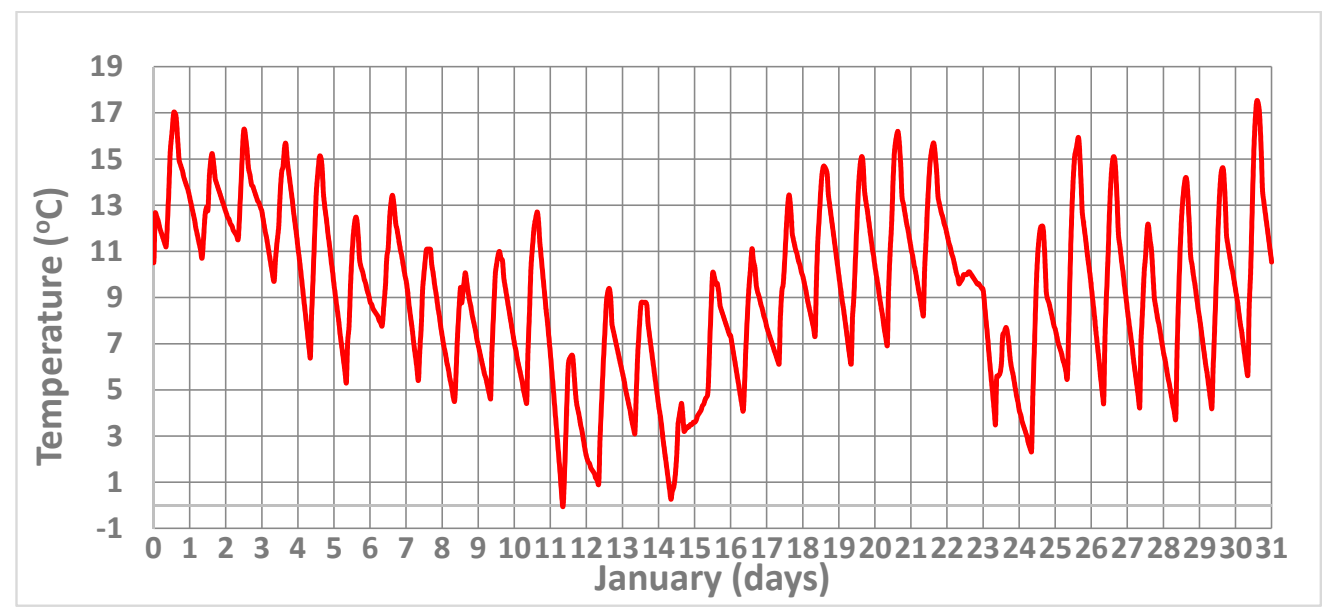

(a)

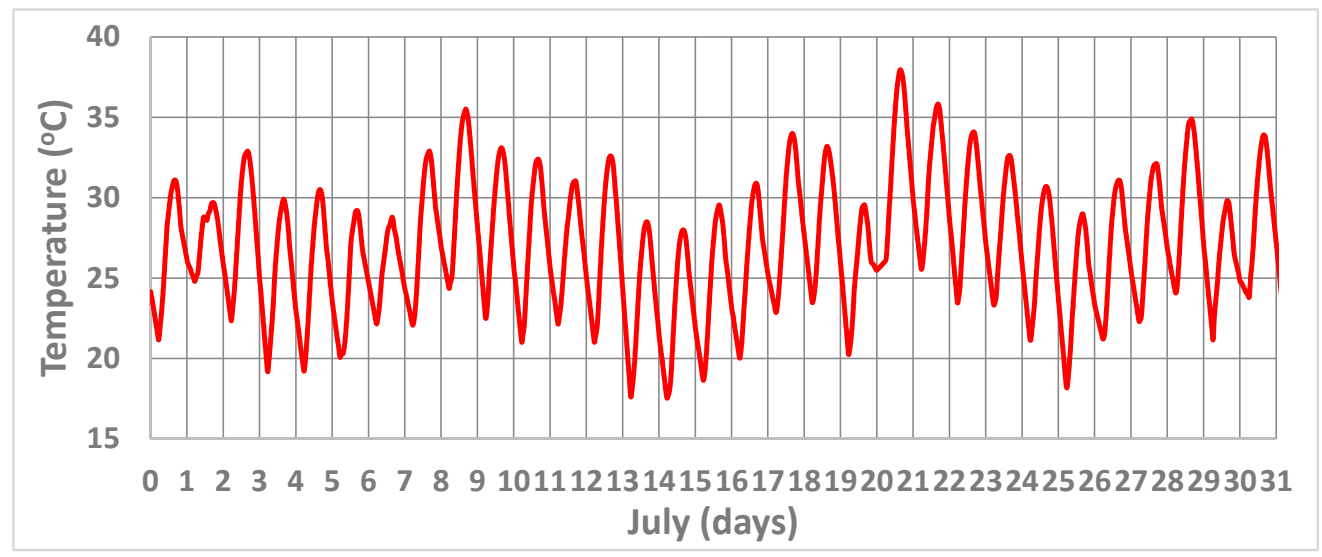

(b)

Figure 3. Ambient temperature of the (a) coldest month of the year-January; (b) warmest month of the year-July. 


\section{Results and Discussion}

\subsection{Energy Demand for Different Cases with and without PCM}

Firstly, the heating and the cooling loads are examined for seven different cases, which are shown in Table 4. Figures 4 and 5 show the yearly heating and the cooling loads respectively for each case. These cases regard different combinations of insulation and PCM in north and south walls. It is evident that the best case for reducing the heating loads is with a single insulation layer on the walls, while the worst scenario is the case without insulation. For reducing the cooling loads, the best case is with insulation in the north wall and PCM in the south wall, while the worst scenario is where there is no insulation in the walls. It is reasonable to find that the cases without insulation are the worst cases, while it is also reasonable to find the insulation beneficial for the building's thermal behavior. Practically, the insulation is a way of reducing the heat exchange between the indoor and the outdoor space. Moreover, the thermal inertia of the walls is increased with the use of PCMs, and this fact makes possible the energy management. Especially for the south wall, the use of PCMs leads to proper energy management in order to reduce the temperature fluctuations in the indoor space.

Table 4. Different cases in south and north walls.

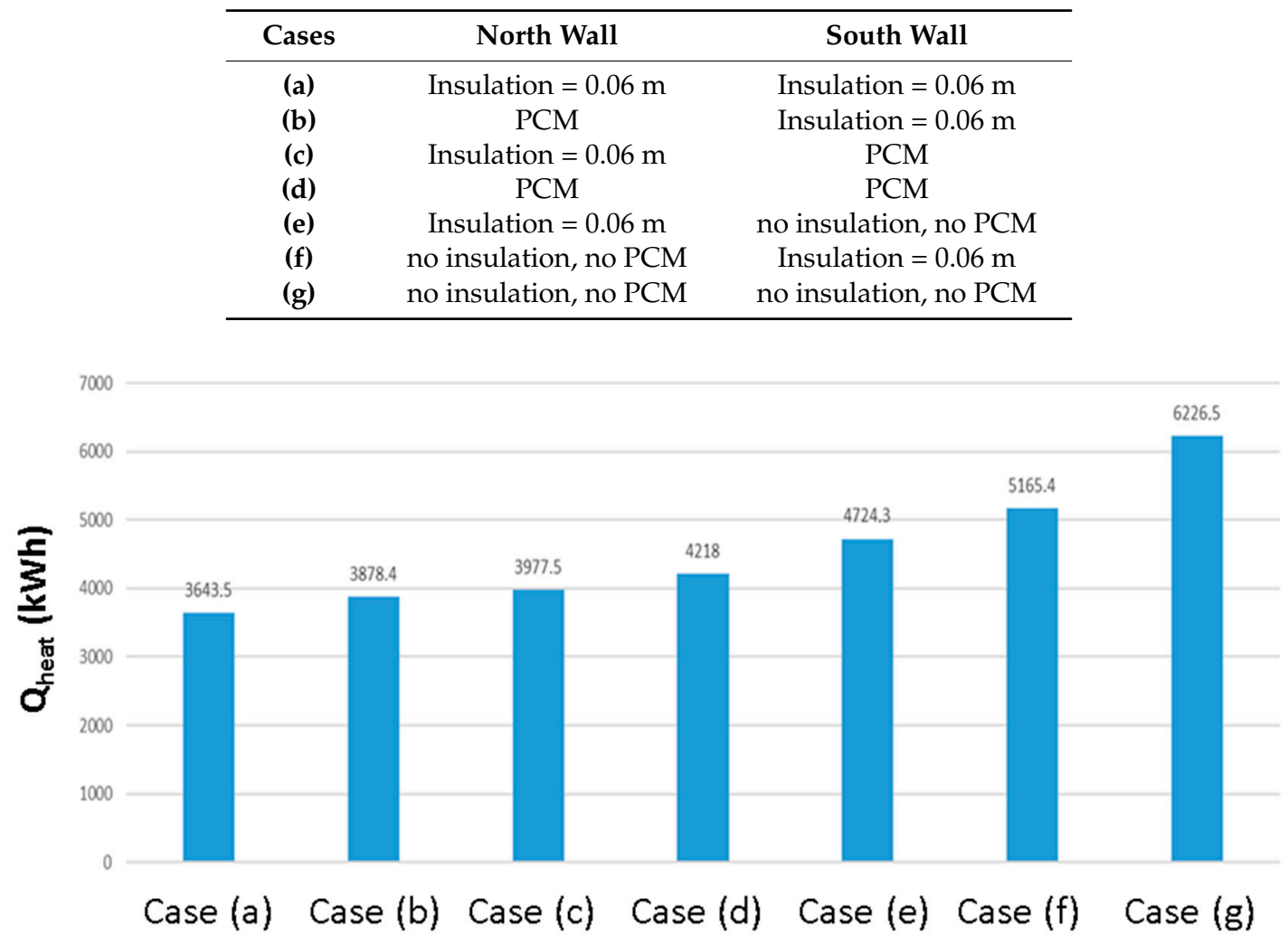

Figure 4. Annual heating loads for the examined cases. 


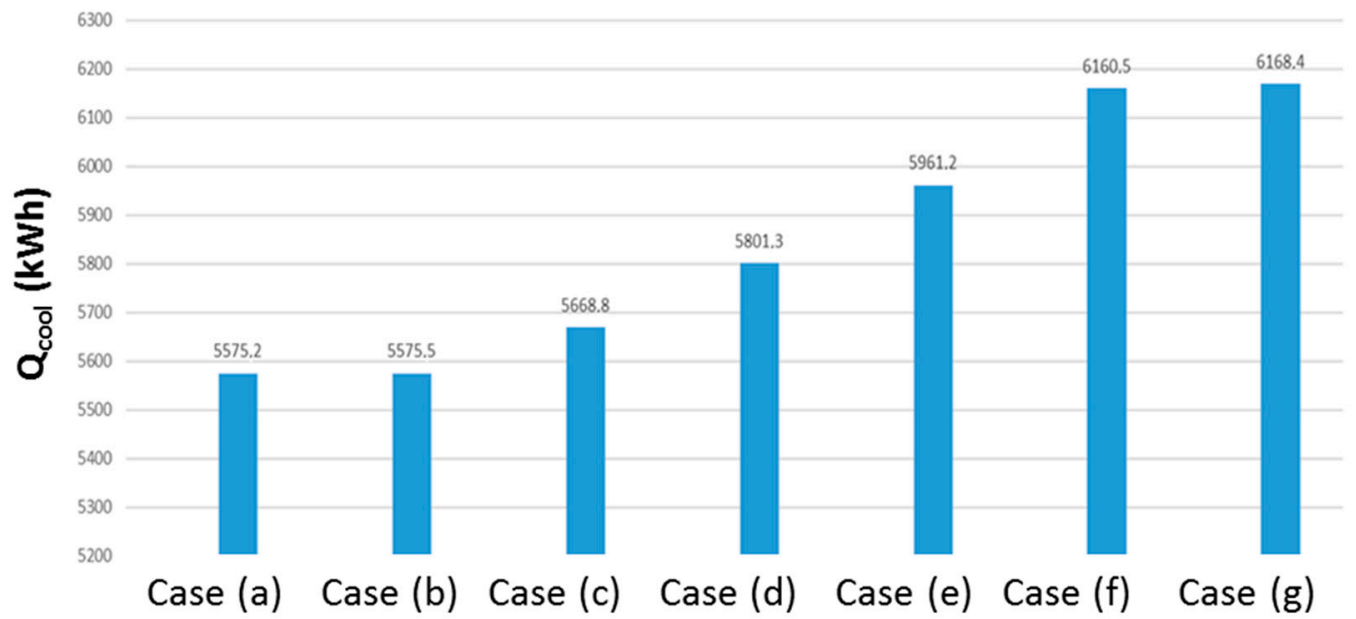

Figure 5. Annual cooling loads for the examined cases.

\subsection{Energy Demand for Different Cases with Variable Insulation Thickness in the South Wall}

The next step is the investigation of different insulation scenarios. Figures 6 and 7 show the annual heating loads and the annual cooling loads respectively without PCM and with PCM after the insulation layer (case 1) and before the insulation layer (case 2) only in the south wall. It is evident that the combination of the insulation and the PCM layer reduces the heating and the cooling loads when the PCM layer in the south wall is before the insulation (case 2). More specifically, Figure 6 depicts the reduction of heating loads with the use of Q25/M91 before the insulation which is $1.15 \%$ to $3.56 \%$ while Figure 7 depicts the reduction of cooling loads with the use of Q25/M91 before the insulation which is $6.08 \%$ to $6.43 \%$. It is important to state that the reduction of cooling loads is higher than these of heating loads since the PCM solidification/melting procedure is operating much better under summer conditions where temperatures are over the PCM melting temperature which is the 25 ${ }^{\circ} \mathrm{C}$. So, the PCM is working better in summer regardless of the position, but in winter, it is working better when it is situated before the insulation.

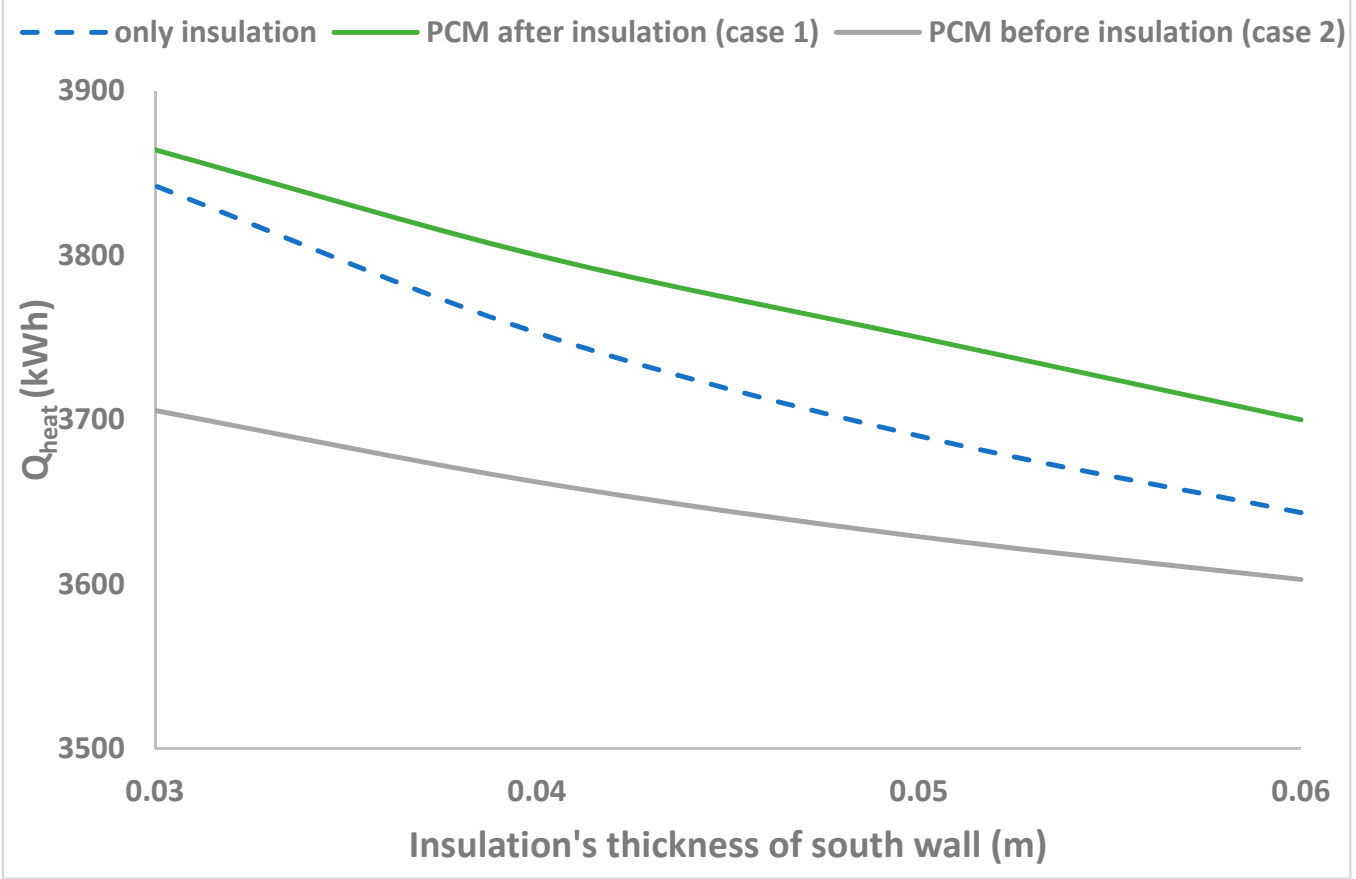

Figure 6. Annual heating loads with PCM in south wall for different insulation scenarios. 


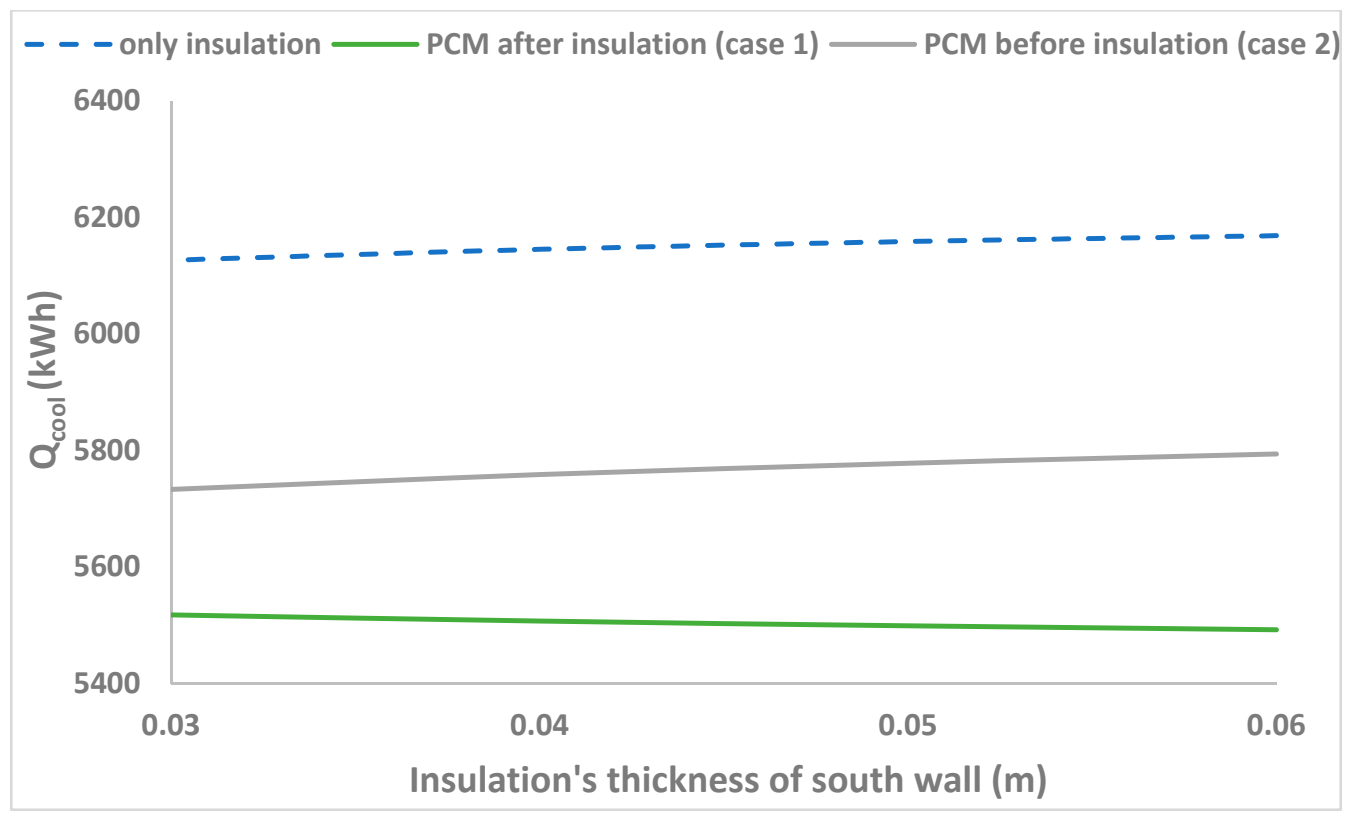

Figure 7. Annual cooling loads with PCM in south wall for different insulation scenarios.

\subsection{Energy Demand for Different Cases with Variable Insulation Thickness in the South and the North Walls}

In this subsection, different insulation scenarios for both walls (north and south) are studied. Figures 8 and 9 show the annual heating loads and the annual cooling loads respectively without PCM, and with PCM in the north wall before the insulation layer (case 3), and after the insulation layer (case 4) in combination with the best position of the PCM layer in south wall which is the case 2.

The best location of the PCM layer, in this case, is when it is before the insulation (case 3). The difference between the results in comparison with the PCM layer before and after the insulation in the north/south wall is imperceptible. More specifically, Figure 8 depicts the reduction of heating loads with the use of Q25/M91 in both walls which is 5.08\% to 10.7\% while Figure 9 depicts the reduction of cooling loads with the use of Q25/M91 in both walls which is $4.67 \%$ to $5.11 \%$. Furthermore, the results showed that we can reduce the thickness of insulation of walls by $0.04 \mathrm{~m}$, and with the combination of a PCM layer, we observe a reduction of heating loads by $1.54 \%$ and a reduction of cooling loads by $5.90 \%$. It is important to state that the PCM is not intended to replace but is instead to complement insulation. The incorporation of PCMs into a structure is effective because all energy savings from PCMs would be in addition to any savings from insulation. The point is that we can achieve a reduction of heating and cooling loads with the application of PCM incorporation with a reduced thickness of insulation. 


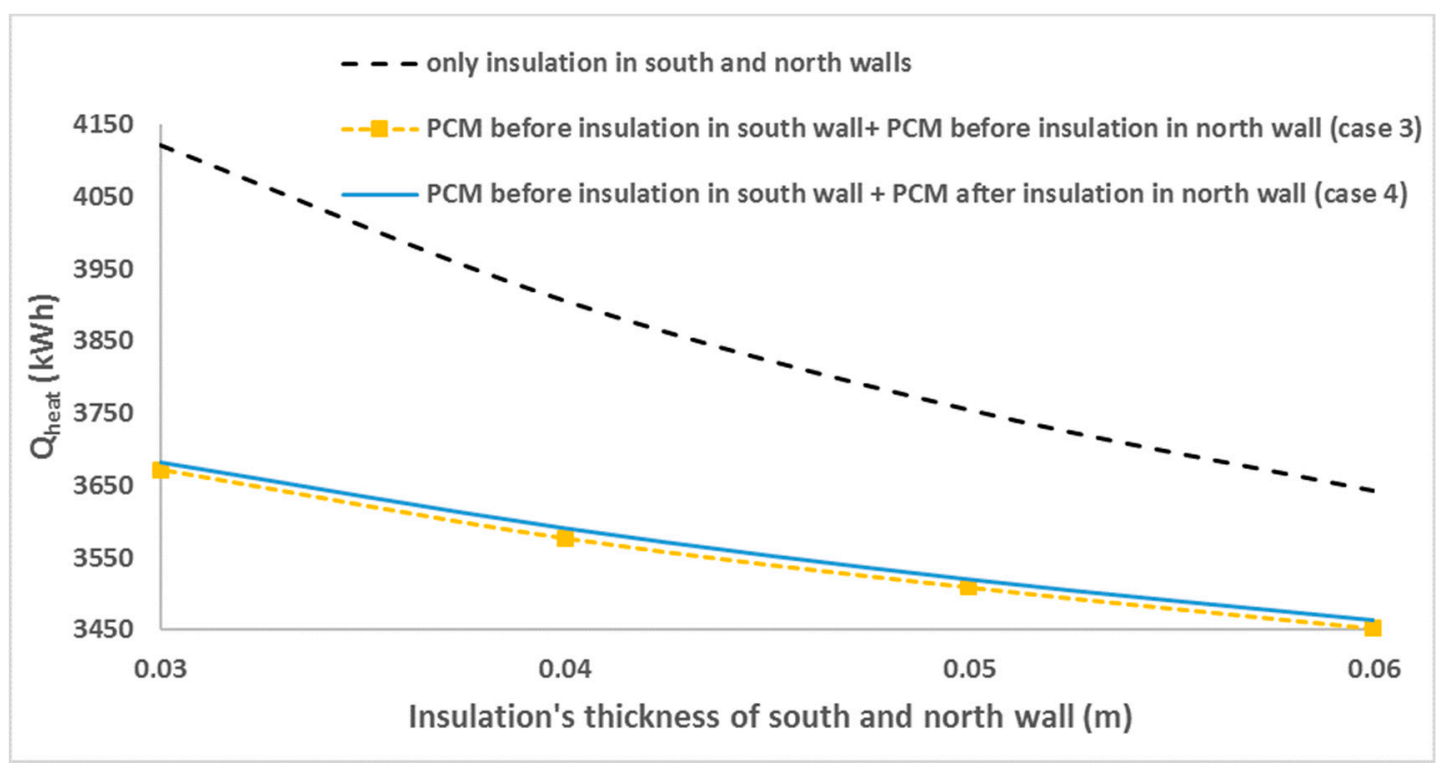

Figure 8. Annual heating loads with PCM in two walls for different insulation scenarios.

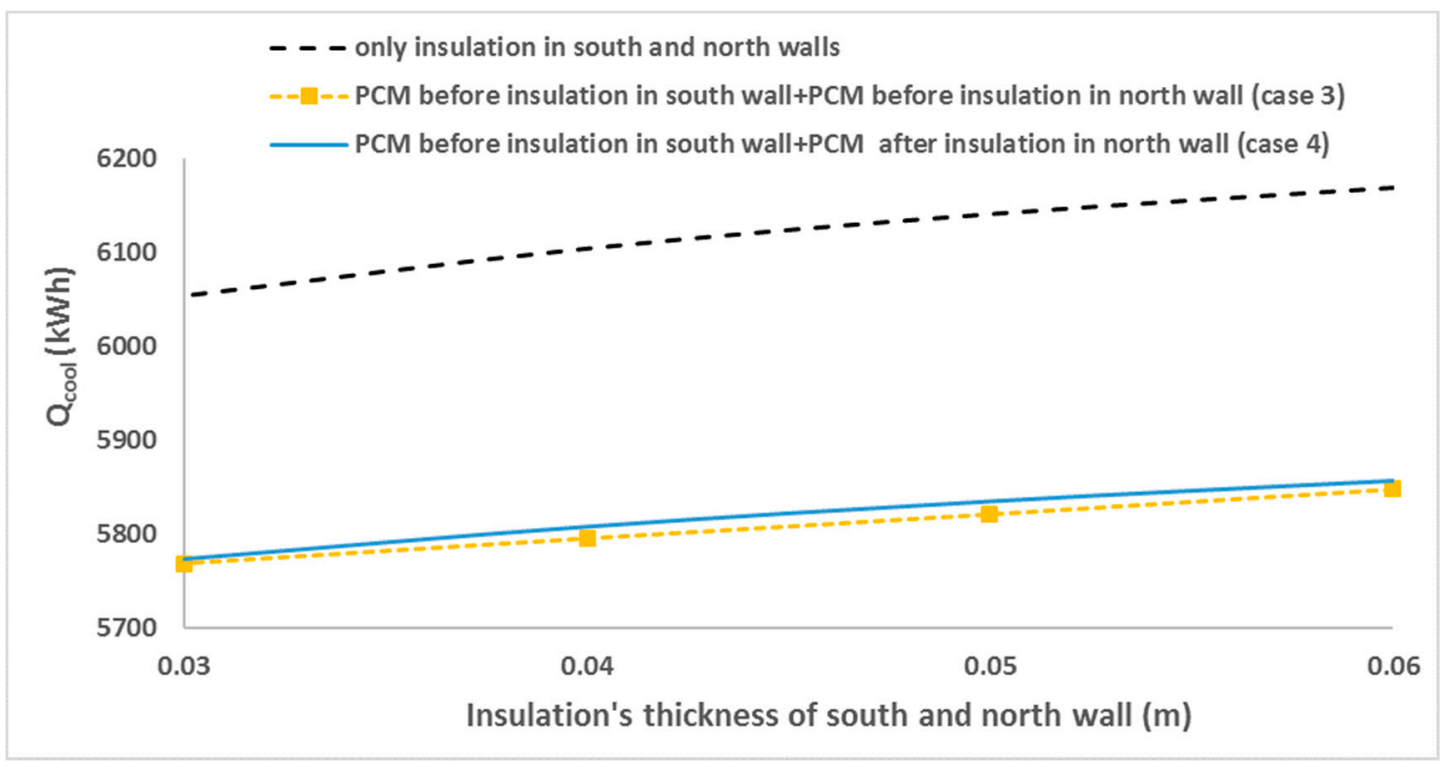

Figure 9. Annual cooling loads with PCM in two walls for different insulation scenarios.

\subsection{Temperature Profiles}

In winter, the temperature in the office has to be higher than the ambient temperature which is near the limits of thermal comfort. Figure 10 shows the temperature's fluctuation for different cases in both walls (south and north) during the coldest day of the year, which is 12 January. It is observed that without insulation the temperature is the lowest among all the cases, which is a reasonable result. The best solution for the winter conditions is the insulation case followed by the combined case (insulation + PCM layer). The combined case has a difference between $0.5^{\circ} \mathrm{C}$ when compared with the insulation case. The difference between the results in comparison with the insulation of $0.06 \mathrm{~m}$ and of $0.04 \mathrm{~m}$ is imperceptible. Practically, the use of PCM increases the thermal mass of the building envelope, and this fact leads to a more stable indoor temperature profile and to lower temperature fluctuations.

By contrast in summer, the temperature in the office has to be lower than the ambient temperature, which is near the limits of thermal comfort. Figure 11 shows the temperature's fluctuation for different cases in both walls (south and north) during the warmest day of the year, which is 22 July. It is 
observed that the best solution for the summer conditions is the combined case (insulation $+\mathrm{PCM}$ layer). The combined case has a difference between $0.2^{\circ} \mathrm{C}$ when compared with the insulation case and a difference between $0.4{ }^{\circ} \mathrm{C}$ when compared with the no insulation case. The difference in the results in comparison with the insulation of $0.06 \mathrm{~m}$ and of $0.04 \mathrm{~m}$ is also imperceptible. Generally, it can be said that the use of PCMs leads to lower indoor temperatures during the summer day.

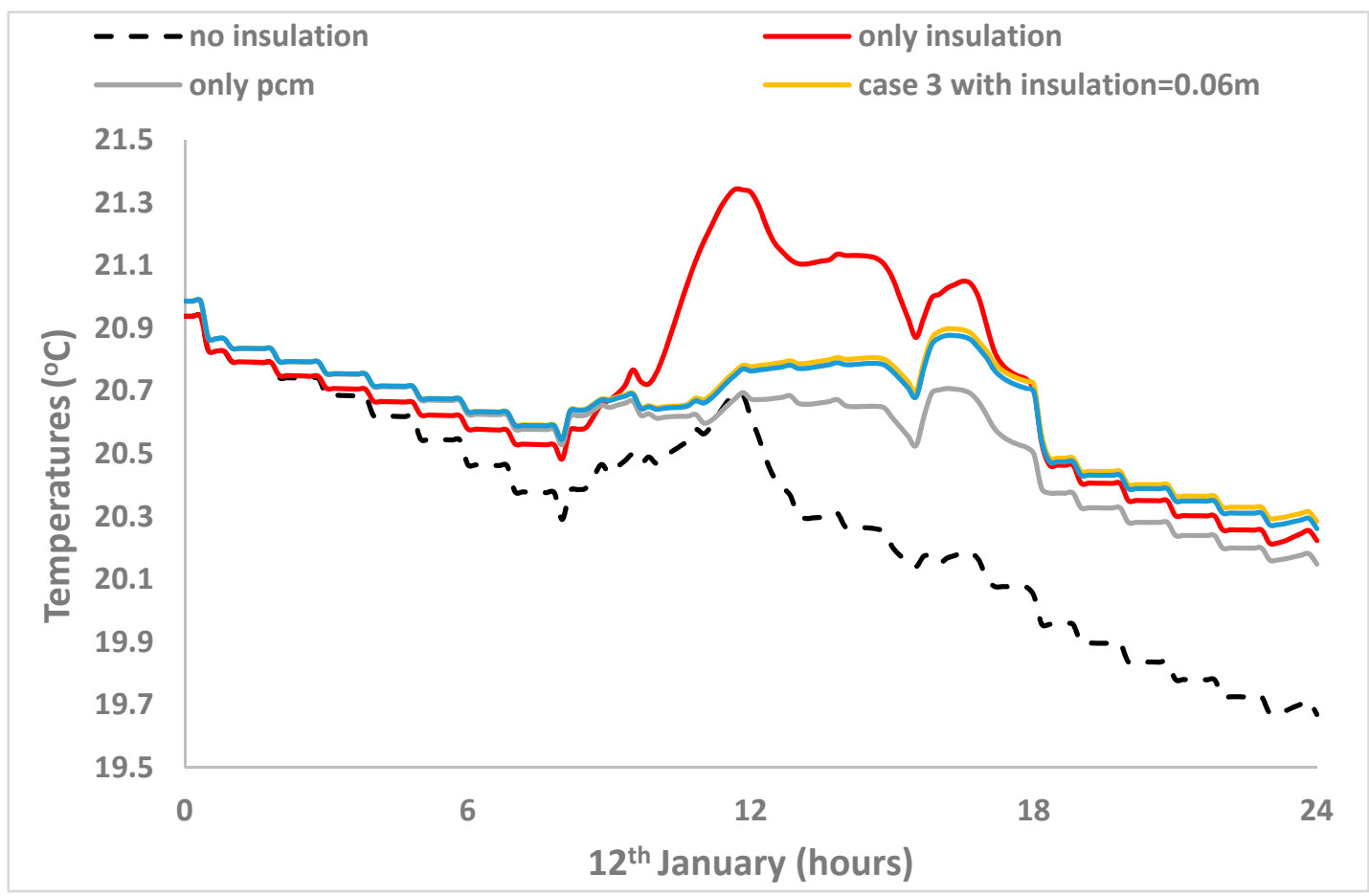

Figure 10. The temperature's fluctuation for different cases on the coldest day of the year (12 January).

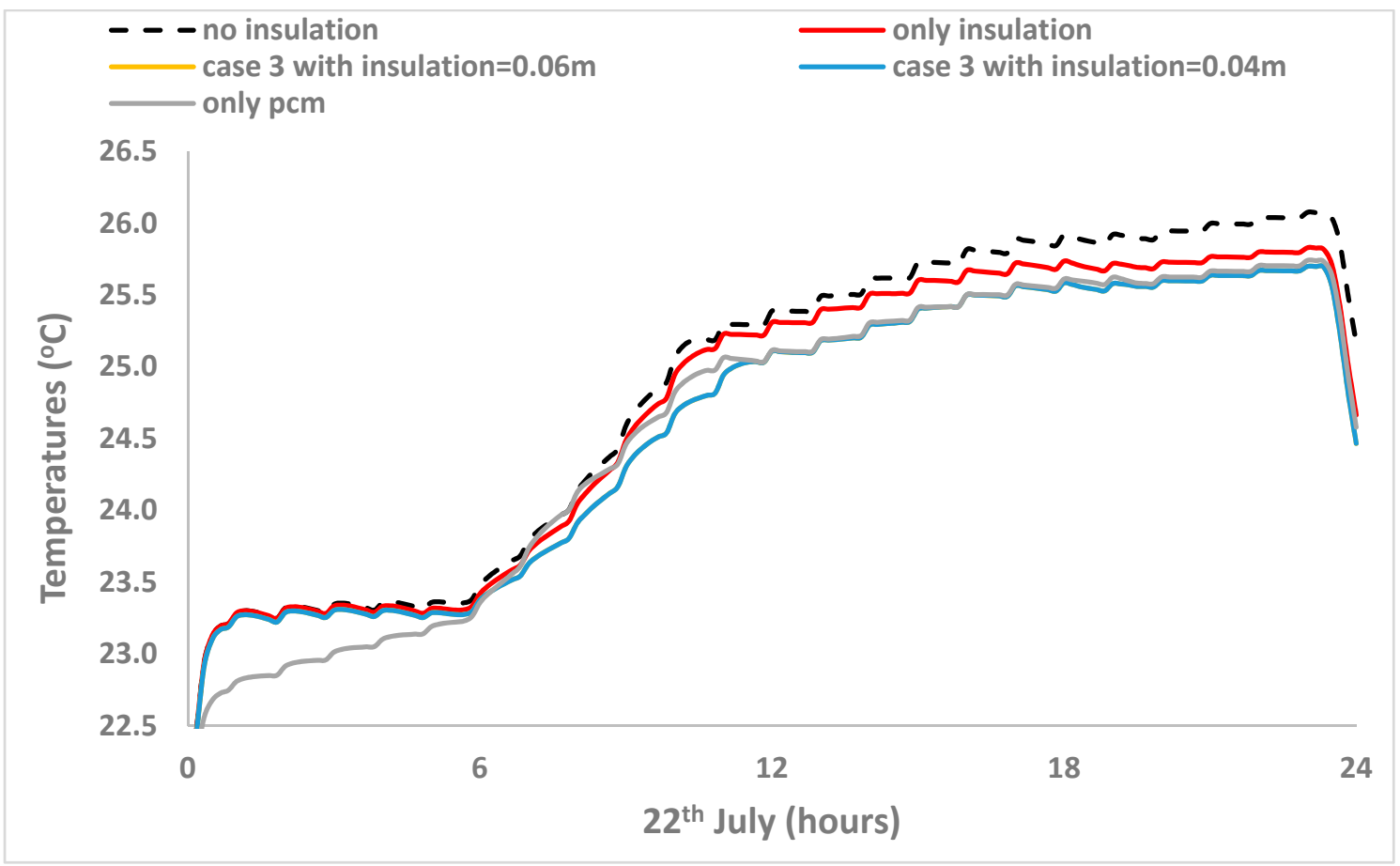

Figure 11. The temperature's fluctuation for different cases on the warmest day of the year (22 July). 


\section{Conclusions}

In this work, a comparison between the heating loads, the cooling loads and the temperature's distribution in an office, with and without the use of a PCM layer in different positions in walls, which is situated in Athens, is presented and is theoretically evaluated. PCM as a wall layer in combination with insulation reduces heating and cooling loads of the office and improves the occupant's thermal comfort during summer when it works well. The best case is when there is a PCM layer in the south and in the north wall before the insulation layer. This happens because in this position the PCM is exposed to external conditions such as solar radiation and thus it is more active. The reduction of heating loads is $1.54 \%$, and the reduction of cooling loads is about $5.90 \%$. As is expected, the cooling loads are reducing more than the heating loads because the PCM operates much better under summer conditions, due to the fact that the temperatures in summer are higher than the PCM melting temperature. Moreover, it is essential to state that insulation works by increasing the thermal resistance of a building, slowing the flow of heat in and out of the structure. PCMs work by increasing the thermal mass of a building and increasing the time it takes for the structure of a building to warm up or to cool down. Furthermore, PCMs are not intended to replace insulation, but they are intended to complement insulation. In the future, the use of PCMs in other walls (east and west) can be examined. Additionally, the uses of PCMs in the ground and in the roof are alternative choices. Furthermore, the use of active heating/cooling systems in the external building components with PCM is an interesting idea which can be studied. The use of solar or geothermal energy can be performed in order to feed, totally, or partially, these active systems.

Author Contributions: Investigation, M.T.P.; Writing—original draft, E.B.; Writing-review \& editing, C.T., I.A. and K.A.A.

Funding: This research was funded by the Special Account Research Funds and from the "Bodossaki Foundation".

Acknowledgments: M.T. Plytaria would like to thank the Special Account Research Funds of the National Technical University of Athens for its financial support. E. Bellos would like to thank the "Bodossaki Foundation" for its financial support.

Conflicts of Interest: The authors declare no conflicts of interest.

\section{Nomenclature}

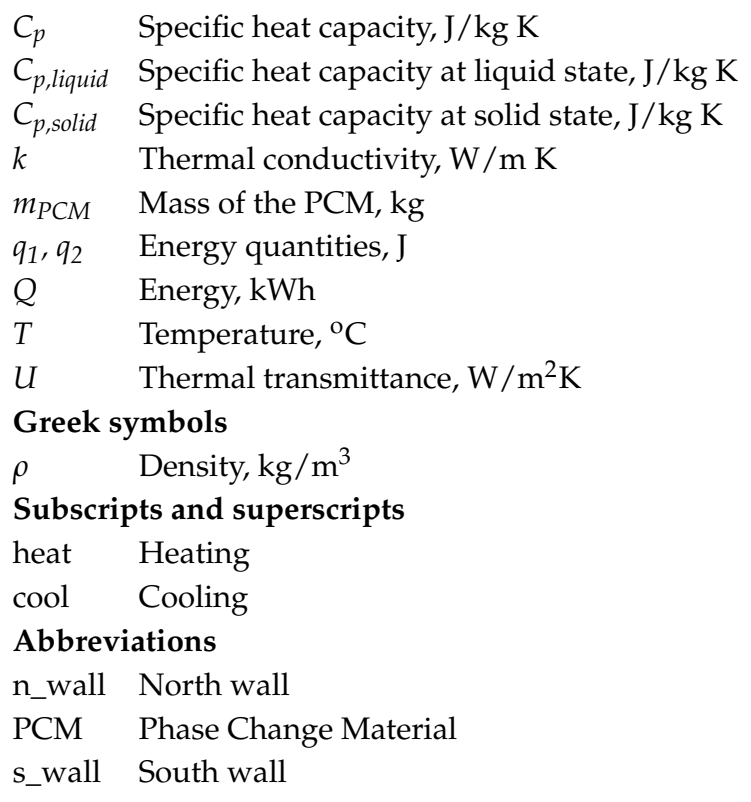




\section{References}

1. Soleimani, Z.; Calautit, J.K.; Hughes, B.R. Computational Analysis of Natural Ventilation Flows in Geodesic Dome Building in Hot Climates. Computation 2016, 4, 31. [CrossRef]

2. Bellos, E.; Tzivanidis, C.; Moschos, K.; Antonopoulos, K.A. Energetic and financial evaluation of solar assisted heat pump space heating systems. Energy Convers. Manag. 2016, 120, 306-319. [CrossRef]

3. Fantidis, J.G.; Bandekas, D.V.; Potolias, C.; Vordos, N. Cost of PV electricity-Case study of Greece. Sol. Energy 2013, 91, 120-130. [CrossRef]

4. Kouremenos, D.A.; Antonopoulos, K.A.; Domazakis, E.S. Solar radiation correlations for the Athens, Greece. Sol. Energy 1985, 35, 259-269. [CrossRef]

5. Kravvaritis, E.D.; Antonopoulos, K.A.; Tzivanidis, C.; Bellos, E. Solar Energy Management Using Phase Change Materials Passive Systems in the Athens Area Buildings. Int. J. Mech. Syst. Eng. 2015, 1, 102-110. [CrossRef] [PubMed]

6. Chou, H.-M.; Chen, C.-R.; Nguyen, V.-L. A new design of metal-sheet cool roof using PCM. Energy Build. 2013, 57, 42-50. [CrossRef]

7. Jin, X.; Medina, M.A.; Zhang, X. Numerical analysis for the optimal location of a thin PCM layer in frame wall. Appl. Therm. Eng. 2016, 103, 1057-1063. [CrossRef]

8. Romero-Sanchez, M.D.; Guillem-Lopez, C.; Lopez-Buendia, A.M.; Stamatiadou, M.; Mandilaras, I.; Katsourinis, D.; Founti, M. Treatment of natural stone with phase change materials: Experiments and computational approaches. Appl. Therm. Eng. 2012, 48, 136-143. [CrossRef]

9. Kuznic, F.; Virgone, J. Experimental assessment of a phase change material for wall building use. Appl. Energy 2009, 86, 2038-2046. [CrossRef]

10. Medina, M.A.; King, J.B.; Zhang, X. On the heat transfer rate reduction of structural insulated panels outfitted with phase change materials. Energy 2013, 33, 667-678. [CrossRef]

11. Al-Saadi, S.N.; Zhai, Z. Modeling phase change materials embedded in building enclosure: A review. Renew. Sustain. Energy Rev. 2013, 21, 659-673. [CrossRef]

12. Ibanez, M.; Lazaro, A.; Zalba, B.; Cabeza, L.F. An approach to the simulation of PCMs in building applications using TRNSYS. Appl. Therm. Eng. 2005, 25, 1796-1807. [CrossRef]

13. Ahmad, M.; Bontemps, A.; Sallée, H.; Quenard, D. Thermal testing and numerical simulation of a prototype cell using light wallboards coupling vacuum isolation panels and phase change material. Energy Build. 2006, 38, 673-681. [CrossRef]

14. Schranzhofer, H.; Puschnig, P.; Heinz, A.; Streicher, W. Validation of TRNSYS simulation model for PCM energy storages and PCM wall construction elements. In Proceedings of the ECOSTOCK 2006-10th International Conference on Thermal Energy Storage, Atlantic City, NJ, USA, 31 May-1 June 2006; Institute of Thermal Engineering, University of Technology Graz: Pomona, NJ, USA, 2006.

15. Kuznik, F.; Virgone, J.; Johannes, K. Development and validation of a new TRNSYS type for the simulation of external building walls containing PCM. Energy Build. 2010, 42, 1004-1009. [CrossRef]

16. Dentel, A.; Stephan, W. TRNSYS TYPE 399_Phase Change Materials in Passive and Active Wall Constructions; Institute for Energy and Building, Georg Simon Ohm University of Applied Sciences: Nürnberg, Germany, 2013.

17. Al-Saadi, S.N.; Zhai, Z.J. TRNSYS Type 285-Phase Change Materials Embedded in Wall System; Department of Civil, Environmental and Architectural Engineering, University of Colorado: Boulder, CO, USA, 2014.

18. Delcroix, B.; Kummert, M.; Daoud, A. Development and numerical validation of a new model for walls with phase change materials implemented in TRNSYS. J. Build. Perform. Simul. 2017, 10, 422-437. [CrossRef]

19. Stritih, U.; Tyagi, V.V.; Stropnik, R.; Paksoy, H.; Haghighat, F.; Joybari, M.M. Integration of passive PCM technologies for net-zero energy buildings. Sustain. Cities Soc. 2018, 41, 286-295. [CrossRef]

20. Fateh, A.; Borelli, D.; Devia, F; Weinläder, H. Summer thermal performances of PCM-integrated insulation layers for light-weight building walls: Effect of orientation and melting point temperature. Therm. Sci. Eng. Progr. 2018, 6, 361-369. [CrossRef]

21. Lu, S.; Zhao, Y.; Fang, K.; Li, Y.; Sun, P. Establishment and experimental verification of TRNSYS model for PCM floor coupled with solar water heating system. Energy Build. 2017, 140, 245-260. [CrossRef]

22. Derradji, L.; Errebai, F.B.; Amara, M. Effect of PCM in Improving the Thermal Comfort in Buildings. Energy Procedia 2017, 107, 157-161. [CrossRef] 
23. Thermal Energy System Specialists (TESS). TESSLibs 3-Mathematical Reference, TRNSYS 17-Volume 5-Multizone Building Manual, Transient System Simulation Program; Solar Energy Laboratory (SEL), University of Wisconsin: Madison, WI, USA, 2012.

24. BioPCM. Phase Change Energy Solutions Australia. 2015. Available online: http://phasechange.com.au/ (accessed on 21 December 2019).

25. Tzivanidis, C.; Bellos, E.; Mitsopoulos, G.; Antonopoulos, K.A.; Delis, A. Energetic and financial evaluation of a solar assisted heat pump heating system with other usual heating systems in Athens. Appl. Therm. Eng. 2016, 106, 87-97. [CrossRef]

26. YPEKA. EK407/B/9.4.2010, Regulation on Energy Performance in the Building Sector (20701-2/2010)—KENAK; YPEKA: Athens, Greece, 2010. (In Greek)

27. YPEKA. EK407/B/9.4.2010, Regulation on Energy Performance in the Building Sector (20701-1/2010)—KENAK; YPEKA: Athens, Greece, 2010. (In Greek)

28. Panayiotou, G.P.; Kalogirou, S.A.; Tassou, S.A. Evaluation of the application of Phase Change Materials (PCM) on the envelope of a typical dwelling in the Mediterranean region. Renew. Energy 2016, 97, $24-32$. [CrossRef]

29. Jayalath, A.; Aye, L.; Mendis, P.; Ngo, T. Effects of phase change material roof layers on thermal performance of a residential building in Melbourne and Sydney. Energy Build. 2016, 121, 152-158. [CrossRef]

(C) 2018 by the authors. Licensee MDPI, Basel, Switzerland. This article is an open access article distributed under the terms and conditions of the Creative Commons Attribution (CC BY) license (http:/ / creativecommons.org/licenses/by/4.0/). 